\title{
Preparing Students And Teachers For Careers In Business: Rethinking The Teaching Of Business At The High School And Undergraduate Levels
}

\author{
Chandra Aleong, (Email: aleong@desu.edu), Delaware State University
}

\begin{abstract}
This is a conceptual as well as a research-oriented paper on the need for a strategic rethinking of business education from middle and high school, to the college undergraduate level. Case studies, interviews, discussions with teachers and school administrators and participation in school advisory councils were the evidence used to demonstrate the urgency for research on this topic. Overall, the findings substantiate the importance of aligning the pedagogy with the needs of the marketplace. Resistance from faculty and school administrators as well as state standards and funding criteria are some of the deterrents to change. This work informs policy makers, teachers and school administrators of the need to streamline the middle and high school business curriculum with the college curriculum and to align the study of business with the current needs of the workplace and society.
\end{abstract}

\section{INTRODUCTION}

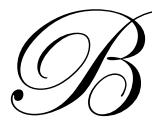
usiness Education is currently facing challenges on many fronts, ethics, effectiveness, orientation, just to name a few. In the business community, reform has become so urgent in the wake of scandals that President Bush signed the Sarbanes-Oxley Act of 2002. This Act calls for governmental oversight and criminal penalties for non- compliance with generally accepted accounting and auditing standards. The question raised by the Academy of Management and by business schools in general is whether they are encouraging illicit behavior.

On the effectiveness front, Gioia and Corley (2002) felt that intense competition between business schools was channeling resources away from pedagogy to public relations. In a landmark paper in "Learning and Education", Pfeffer and Fong (2002) laid out the argument that business schools are "less successful than meets the eye"; that they are not meeting the needs of business. This critique sent ripples throughout the business and academic population, especially since enrollment in business schools has been at an all time high in the last decade. Trank and Rynes (2003) questioned the direction in which Business Education as an organizational field was heading, that is further away from professionalization.

The focus of this paper is to examine the nature of business education at its very roots, that is, at the middle and high school levels. How are students introduced to "business" as an area of study? Lack of an accredited and agreed-upon body of knowledge, and of transition points in becoming a professional are underlying elements influencing pedagogy, curriculum and assessment.

The research findings indicate a lack of direction and cohesiveness. Medicine and Law have evolved as organizational fields such that all interested parties are aware of the requirements in becoming a physician or a lawyer. With business there is the nagging sense that having credentials is important but experience and luck might be sufficient for success. The case studies of successful businesses started by entrepreneurs who were not educated in the field of business are numerous. Members of the profession such as Ackoff, 2002 and Pfeffer \& Fong, 2002, are of the opinion that "management is best taught as a craft, rich in lessons derived from experience". Trank and Rynes, 2003, 
expressed fear of de-professionalization in the following statement, "if we are not careful, we run the risk of devolving to the point where business education was in the 1950s". James Howell, in Schmotter, 1984: 9, cited in Trank and Rynes, 2003 felt that business education was "irrelevant to most students, to employers, and to society ... because of the narrowness of the training provided".

The issues of vision and uncertainty of what comprises business education are examined in this paper. Authors such as Gioia and Corley, 2002; Zimmerman, 2001, and Abrahamson and Eisenman, 2001 have articulated the belief that undergraduate and graduate business schools are losing influence. The contribution of this paper is to examine what is taught at the middle and high school level and to understand whether there is a smooth transition to college business programs. First there is an overview of the current state of business education as well as the overall business environment. Next is a description of the case study method and the findings that emerged from the research. The final section discusses the role of technology in education and areas for further research.

\section{OVERVIEW OF BUSINESS EDUCATION}

"Business education" at the middle and especially the high school level is a misnomer. The current philosophy and curriculum are more in line with teaching administrative and office procedures, basic technology courses, and in some cases bookkeeping and entrepreneurship. Given the widespread use and availability of technology, as well as the more dramatic changes that have been made in the workplace, there should be a rethinking of how business is taught at the middle and high school levels. This critique does not address undergraduate programs of business housed in a management department although some issues of business education in an Education program will be discussed. The educational process should enable the graduating high school senior to have a seamless path for entry either into the workplace or into college business and education programs.

Despite all the uncertainties of the field of business, it is well established that educating students requires an understanding of the principles of business as well as a sound experience base. The professions of law and medicine demand a similar integration of the theoretical and the applied. In addition to the theoretical and experiential bases, students should have opportunities for interaction with business leaders, university, and other related professionals. The importance of this integration is well documented in the works of Darling-Hammond, 1997; and Freppon, 2001. Apprenticeships, partnerships, and alliances have always been considered to be beneficial for all the parties involved, the student, the cooperating partner and the institution. Research on the benefits of the Professional Development School (PDS), a school-university partnership is a good example of how educators have found ways to create alliances and learning experiences for students and teachers. PDS teachers assume responsibilities that Frankes, Valli, and Cooper (1998) describe as teacher as decision maker, teacher as teacher educator, teacher as researcher and teacher as political advocate.

This brings us to the research question, "Are students in business education programs at the secondary school level given a sound education in the principles of business with opportunities for field work?" The findings from the case studies seem to indicate that this is not the norm.

\section{Current State of Business Education}

Based on its historical roots in the technical school tradition, the business education curriculum centered on training secretaries to type, take shorthand, operate office equipment, organize and maintain a filing system, and other office administration type activities. Drastic changes in the work environment have evolved into the expectation that every employee from the manager on down must have working knowledge of Microsoft Word, Excel, PowerPoint, and a data base application software such as Access. While it is important to prepare high school graduates to use these application software packages, should this be the domain of the business education department? The No Child Left Behind Act states that by 2006 technology must be incorporated into the curriculum. That puts the onus on teaching, using, and integrating technology on all participants. Application of business software has become an indispensable ingredient in the completion of assignments and in presentation of data. Students have become accustomed to typing reports in Word, using PowerPoint for class presentations, and organizing data using Excel or Access. A more important question challenge would be to determine the mechanism by which everyone would learn and use hardware and software more effectively. Due to the pervasive nature of computers in homes, schools and 
libraries, mandatory summer workshops might the solution, thus leaving the academic school year available for teaching principles and content. The current setup begs the question as to why the full semester and entire school year be dedicated to teaching technology to a handful of business education students? It seems that the current curriculum is depriving the school population of the benefits of knowledge of technology. On the flip side we might be "dumbing" down the education of those students who want to pursue business as a career.

High schools and business education programs in colleges of education persist in emphasizing basic microcomputer application courses, document formatting, typing, and office administration. Classes still involve training students how to use fax machines, printers, and other office equipment. The prevailing mindset is to prepare the high school graduate for a lower-tier office position as an administrative assistant, office secretary or bookkeeper. The goal of laying the foundation of becoming managers, investment bankers, accountants and financial analysts is not the centerpiece of the business curriculum. A good counter example would be the curriculum for students who want to pursue science. They learn the principles of biology and chemistry in high school and this leads them to different career paths. The business education major is not getting the same type of training and knowledge.

A major problem with the school environment as it relates to business education is the lack of focus given to business as a primary area of study compared to science, mathematics or the liberal arts. These latter areas are considered core courses that all students must take and pass before they can graduate. State tests and accountability criteria are designed around them while business courses at the high school level are considered electives and do not get the recognition or the recommendation from teachers and counselors advising students. The entire school community including parents have the perception that these classes have a vocational rather than an academic or college-bound orientation.

Given the dominance of business in modern society, business courses should have the same prominence that the three R's have. Reading, Writing and Arithmetic should be joined with some appropriate identifier for understanding the role of business in an industrial economy. An education system that prepares students to read and understand basic financial statements might avoid the major losses that Enron's shareholders suffered. Budgets, insurance policies, taxes, savings accounts, social security, pensions and other retirement accounts are common areas of interest to people of all ages. As adolescents join the workforce at progressively younger ages, students should graduate from high school with an understanding of the meaning and implications of these terms rather than coming upon them in a haphazard way. The urgency of obtaining this knowledge is even more apparent in the current political climate when the burden of retirement planning and health care is expected to fall partially or solely on each individual citizen. Government participation in subsidizing and participating in social programs is dwindling thus the urgency for more education on business issues at an early age.

\section{Business, Educational And Office Environment}

In the last two decades there have been major changes in business and technology and its influence on every aspect of society. The stock market experienced its fastest rate of growth during the Internet bubble with small, medium and large businesses exploring the use of an e business format in conjunction with a brick and mortar structure. Companies like Microsoft, Google, and Dell became household names alongside the former stalwarts like International Business Machines, General Electric and General Motors. Small investors learnt about the advantages of diversifying their portfolios with companies like Vanguard and Charles Schwab. There was also an explosion in the marketing of products and services with a simultaneous expansion of new media outlets, such as cable television, the Internet and telemarketing. Business and technology have permeated the lives of every individual both locally and globally.

Education during this era also became big business. The average annual cost of an undergraduate education tripled and even quadrupled at some institutions. The largest growth area has been the non-traditional business schools both for undergraduate, but especially for graduate M.B.A. degrees. Competition for students has intensified as high school graduates jockey for the limited number of spots at the top business schools selected by Business Week. Nontraditional schools have sprung up all over the U.S. and Canada, with the University of Phoenix being the best example of this phenomenon. The business departments at every university have become the cash cows of the university. The influx of high school graduates flocking to business departments to get the bachelor's degree and of 
adult students either completing a four-year undergraduate degree in business or pursuing an M.B.A. is still continuing and there are no signs of this slowing down in the near future.

The demand for slots at the more prestigious institutions is very competitive. Universities are constantly raising the entry requirements with higher SAT and GPA scores and an advanced portfolio of curricular and extracurricular activities. Against this backdrop is the reality that teachers are not equipped to assist high school graduates to reach the elevated standards because they themselves are not prepared and because state standards and the curriculum do not reflect the current needs of the marketplace. As a result the pipeline of students entering the more prestigious business programs comes from private schools or schools in more affluent districts. The less-equipped student starts with a disadvantage and has to spend considerable time covering the basics before beginning to learn the material that is expected of them.

Given the business, educational, and office environment described, the premise of this paper is that the underlying philosophy of business education programs is not well suited to the current needs of students. However, since schools follow criteria set by the state, the problem has to be resolved with a change in policy. This would involve a broad network of parties interested in the outcome such as parents, students, state officials, school administrators, employers, and universities. Schools would include middle, high, vocational, technical, and technical colleges, among others.

\section{METHOD}

The case study method was used as the method of inquiry. As Yin, 1994 and Stake, 1995 stated it allows the researcher to capture and describe the complexity of real-life events. The researcher was able to obtain information on attitudes and opinions that the respondents might not have divulged otherwise. In addition, the database is too small to have a good random sample. As discussed earlier, the number of students selecting business education courses at the high school level is declining which causes the demand for business teachers to decline. This downward spiral leads to other problems such as fear of losing a position, of being denied tenure, or of being considered a troublemaker. The case study method lends itself to getting contextual data from participants in a study like this.

\section{Participants And Data Sources}

The participants in the study are business education teachers in several school districts across the state. The cases are based on classroom interviews, reports, discussions, and participation in advisory councils of several high schools. Some teachers have been in the classroom for one to two years, some longer. They were asked to describe their schools, departments, school policies and other topics related to teaching courses in business education. The teachers wrote the reports with the condition that their views be kept confidential because of fear of upsetting the supervisory personnel at their schools. Concerns such as keeping their positions, getting tenure, and other job security issues were common. Most of the respondents were graduates of business schools, some with a bachelor's degree, others with graduate degrees in business administration. Most had worked in a corporate environment for a few years and were pursuing teaching because of several reasons; inordinate amount of travel, downsizing, more flexibility with the start of a family, dissatisfaction with the corporate lifestyle etc.

\section{FINDINGS}

\section{Enrollment}

Enrollment of students in the business pathway has declined in the last two decades. Faculty is hired to increase enrollment of business education majors but it is a losing battle. The case studies show evidence of this downward trend. In one school, a teacher doubled the number of students enrolled in accounting. This sounds good but the beginning base was small. At this same school, the number of students taking computer classes did not increase and as a result one of the business teachers was asked to move to the middle school. Another indicator of decline is involvement with Business Professionals of America (BPA). Participation in BPA decreased at this school over a three-year period. In 2002 ten students were involved. This dropped to eight in 2003 and to six in 2004. All business students at the high school level are expected to attend the BPA conference. 


\section{Core Versus Non-Core}

Another problem area that was a common thread for all teachers was the lack of focus on business education because it is not considered "core". Given the current emphasis on testing, schools are more concerned about meeting the standards of core classes. The main objective is passing the state standards tests. The business department does not have prominence relative to other departments and is considered secondary to those of the core areas.

Business education classes do not attract college-bound students because they are considered to be "electives". This is contrary to market conditions which show that a large percentage of students choose to attend business school and should take business courses to prepare them for college. As one teacher remarked "many students perceive the "secretarial" or "computer" classes as fillers for spring semester schedules after fulfilling all the prerequisites for entrance into college.

\section{Current Course Offerings - High School}

Courses offered at the secondary school level are Keyboarding; which involves touch-typing of reports, business memos, business letters, graphics; Advanced Keyboarding which involves advanced Word applications techniques, Excel, PowerPoint, and Access; Business Technology where students learn methods for taking and transcribing notes; telephone etiquette, filling out work applications, filing, and using a numeric keypad or calculator; and Office Administration. As expressed earlier these courses are not as useful or relevant as they were in earlier eras when shorthand was a necessity for secretaries or when it was the norm for each manager to be assigned a secretary who typed, filed and met the administrative needs of the boss.

Some schools offer an introductory and advanced accounting strand where students use the application software Peachtree. The problem observed about the emphasis of accounting as against marketing, finance or human resource management harks back to the old linkage between business education, secretarial services, and bookkeeping. Accounting gets a reputation of being dull and even difficult because students are introduced to it only with debits and credits inherent in a bookkeeping course. Students are not shown how the use and analysis of basic financial statements can open up a whole arena to them such as investment in the stocks of companies or to careers in the six figure types of jobs associated with being a partner in an accounting firm or investment banking. When one member of an advisory council to an area high school was asked how accounting can be made more attractive, the suggestion was that the faculty should find a way to make it "sexy". That was considered to be a foreign concept to some of the business education faculty who had come up in the traditional typing, shorthand and bookkeeping route. If students begin at the middle school level to understand how exciting and useful all the areas of business are there might be a higher rate of entrepreneurship and awareness of the importance of common business basics. Good credit ratings, savings for investments, the pros and cons of purchase versus lease, and implications of tax policies are just some of the fundamental areas that should be an intrinsic part of every middle and high school curriculum. There are large segments of the population who graduate from high school and college and do not have a clue about how to manage money; plan for retirement; or have an awareness of investment in stocks, bonds, or real estate. Given the current political environment where Social Security retirement benefits are expected to be privatized, there is even more urgency for the very young to understand basic business concepts about managing money.

A review of one public school district shows the following courses under the Business Education curriculum: Formatting/Word Processing/Computer Literacy; Database Management, Spreadsheet Management; Advanced Word/PowerPoint; Desktop Publishing; A+ Basics; Website Development; Business Math; Introduction to Accounting; Advanced Accounting; Computerized Accounting and Business Cooperative Work Experience. One of the objectives of obtaining a high school diploma is to give students work skills to enable them to obtain employment if they choose not to continue to college. As Eileen Perrigo among several others has stated, students are entering the work force without adequate communication, teambuilding, and critical thinking skills. (Perrigo, 1994) The current menu does not equip students with the skills to communicate in the basic areas of business, Marketing, Finance, Human Resource Management, Economics or Personal Finance. 


\section{Data From The Business Community}

Business leaders felt that typing and other secretarial oriented courses are not as important as interviewing techniques, entrepreneurship, business law, finance, communications, and business ethics. One employer described how students dressed inappropriately for interviews, did not make eye contact, and were inarticulate. An example was given of one student whose typing speed was excellent but had no chance of securing a position because she failed to impress the interviewers or present herself in a professional manner during the interview.

There is a difference of opinion among business leaders and teachers with a "business administration" program versus those with a "business education" degree. The former think that schools are preparing students with computer skills but denying them the opportunity to acquire the skills that are really needed for employment. One teacher stated that instead of the capstone course being the equivalent of a comprehensive business plan or some similar comprehensive requirement, the current course requires students to build a website and know how to use Microsoft Publisher. This teacher was of the opinion that students were graduating with the opinion that the business degree at the college level is about making fliers and knowing how to file. Another frustrated teacher was of the opinion that she was asked to put aside her expertise and content knowledge and teach telephone etiquette or how to create a brochure. "Teachers are preparing students to surf the Internet or create a flier for a bake sale" was the comment of one teacher.

\section{College Course Offerings}

In a review of business education programs at the college level, word processing and document formatting are still on the curriculum at some institutions or had only recently been removed. One program that was being revamped could not get state approval of its program unless it included document formatting with one of its courses. It was included with the capstone course. There is also the expectation that there should be a course in office procedures, which would focus on use of the Internet and how to file, and use fax machines. This demonstrates the need for a strategic rethinking of the organizational field of business education at every level; Federal since funding is tied to the current curriculum; State since testing standards and funding are based on current course offerings; College since there is need to review course requirements as well as teacher-training programs; and the local school district which is following state requirements. One very fundamental area requiring immediate change is the criteria for funding from federal and state authorities. Grants and budgets do not get approved unless there is a strong emphasis on technology versus an emphasis on teaching business principles.

\section{Attitudes of Resistance}

The comments and reports of the teachers interviewed reflect that a major barrier against change is the veteran business education teacher who in most cases might be in a senior faculty position. This individual generally received training in a different era, got a business education degree, and is not likely to embrace change or be sympathetic to the recommendations made by the new business administration graduates. In one situation, even when senior administrators demanded changes in the curriculum and a more applied approach to teaching, the current business education faculty resisted. The pervasive attitude is that the individuals demanding change do not really know or understand the business education field so they do not get "it". Generally these teachers have tenure and have little motivation to change because they are following job descriptions under which they were hired.

\section{Bureaucratic Barriers}

Another barrier to change is the bureaucratic process of adding new courses. The teachers in the study stated that it was easier to get an elective added for a 45 -minute time slot than a 90 minute-slot. However, they felt a 45 minute slot was insufficient to cover the material. Because of attitudes of members of the department as well as state regulations, the impression was that there are so many bottlenecks at the department, school, district and state level that the new teachers tended to lose motivation to change after the first few years. This frustration is well documented in research done on new teachers by Susi Long, 2004. As stated in a recent article "Separating Rhetoric From Reality: Supporting Teachers in Negotiating beyond the Status Quo" Long found that new teachers who had demonstrated exceptional knowledge and ability during their pre-service program, described a growing desire to leave the 
profession during their first year in the classroom. The teachers in this study expressed similar frustration. Several teachers were interviewing for other positions. Others gave the impression that they were muddling along. None of the teachers expressed passion about their current situation.

\section{Research on Technical Schools}

The research conducted by the organization called High Schools That Work as well as other literature reinforce the widely held perception that vocational programs are not sufficiently challenging. Results of surveys reveal that students in these programs do not have high expectations. The level of math, reading, writing and computer usage is too low or uninspiring. Interviewing techniques, presentation skills and all the above-mentioned business courses are not covered. In a follow-up study done two years after one cohort of vocational students had left high school, $75 \%$ of the respondents said they were not challenged and prepared because they only did basic typing and secretarial-type courses.

\section{DISCUSSION}

\section{Plans For Improvement}

The Business pathway improvement plan should begin with an inventory of what schools are offering and what employers and colleges require students to know to make them better candidates for entry. Content knowledge in the secondary school business program should dovetail that of freshman courses at college. Introduction to case studies, multi-media presentations, entrepreneurship ventures and other creative projects that bridge the theoretical with the applied, would prepare students more effectively for college and the workplace. Not only would the transition be easier but it would also allow the secondary schools to be the natural pipeline for recruitment into business programs at college.

Each school should use a standardized accountability measures for all areas of study, whether it is technology, accounting, or marketing. For example the current measure for technology courses should be certification in the specific software application program such as Word, Excel, PowerPoint or Access. Classes should be aligned to the certification standards of the specific area of study. In this way students would be more inclined to choose a business pathway because of the recognition of these standards by employers and colleges.

Another recommendation is for active participation by employers and state representatives in determining the content of the curriculum as well in lobbying for changes at the federal, state and local levels. Active participation of every group with a vested interest would help to break through the bureaucratic web and make the changes easier to implement.

\section{Change Of Name}

The term "Business Education" should be replaced with the names of areas of business that the school has chosen to specialize in. This would send the right message to the employers and colleges where graduates are applying. For example, finance, accounting, and management could be under a department of management; information systems could be in a management information systems department etc. Although this is just a change of name it would reflect more carefully what the students are majoring in and its relevance to the needs of today's workplace. The urgency to rename and revamp the curriculum by adding and eliminating courses that are more relevant to current times is critical.

\section{Benchmarking And Vocational Programs}

HSTW has recommended that vocational courses: model the concept of quality work; make students independent learners; encourage them to be active rather than passive participants in the learning process; give students open-ended problems to solve by using academic, technical and personal skills. 
Faculty and administrative staff of vocational programs have been trying to improve by getting advice and setting up partnerships with local universities, businesses, and employers but the changes are slow. The industrial workplace that was designed more than fifty years with the advent of the assembly line is still the mindset for planning vocational and business education programs. This was an environment where employees needed constant supervision and were not asked to think. Managers did that for them by solving the critical problems. The expectation in the modern workplace is that workers should not be treated as cogs but should take responsibility for productivity in the organization. Schools have to prepare graduates for the new environment.

\section{Technology And Education}

The goal of this paper is not to reduce the role of technology in teaching business or business education. The goal is to put technology in its correct perspective. Thomas Glennan and Arthur Melmed (1996) in an article prepared for the Rand Corporation titled Fostering the use of educational technology: Elements of a national strategy made the point that technology is a means to an end, not an instructional activity. It should be applied and exploited for learners to meet their instructional needs. A deep-seated knowledge of all aspects of technology requires the educator to go beyond the basic understanding of how it works. It must be understood in a manner that would enable educators to maximize its benefits. This is the case for teaching business as well as for teaching any other subject. In the case of other subjects taught in high school like biology, the curriculum is not focused on the instruments or the technology. The focus is on the fundamentals. The fundamentals of business are found in the principles of accounting, finance, marketing, or management not microcomputer applications.

Larry Cuban (2001) in his book, Oversold \& underused: Computers in the classroom discussed some of the issues that lead to resistance of technology by teachers. Cuban found that the utility of new technology was grounded on perceptions on whether technology could improve teachers' effectiveness in the classroom. The amount of time required to learn and to integrate technology was a major concern of teachers. This concern reflects a more deepseated problem; the fact that in the school system technology is approached as a stand-alone subject in the curriculum. Technology courses should not be the domain of one department. More integration means all students and faculty are exposed to technology classes to become more technology literate.

\section{RECOMMENDATIONS FOR FURTHER RESEARCH}

Business education needs to be studied as an integrated organizational field. There is need for an outlook of what this field of study would look like five, ten, fifteen years from now. For example, in the future voice-recognition technology would completely change how we view the act of typing and keyboarding. Computer literacy 101 as a prerequisite for all high school graduates might become unnecessary. Some areas that require further research are as follows: What are the components that would form a continuum of knowledge from middle/ high school to college? Should technology be viewed as a stand-alone field of study or should it have as much prominence in the pre-college business curriculum? What role should theory have relative to application (in the form of case studies) in the overall education of business students? What emphasis should be placed on long term societal needs versus immediate marketplace demands? Can this field ever be truly considered a profession in the same way that law and medicine are viewed? Trank and Rynes, 2003, in their argument for professionalizing business education asked a very important question, "What are the transcendent values that might be thought of as fundamental to education for a business profession?" Discussion and research to answer this important question needs to take place since business affects the lives of every individual who lives in this global society.

\section{REFERENCES}

1. Abrahamson E. \& Eisenman, M. (2001). Why management scholars must intervene strategically in the management knowledge market. Human Relations, 54: 67-75

2. $\quad$ Ackoff, R. 1. (2002). Interview by Glenn Detrick. Academy of Management Learning and Education, 1: 5663.

3. Cuban, L. (2001). Oversold \& Underused: Computers in the classroom. Cambridge, MA: Harvard University Press. 
4. Darling-Hammond, L. (1997). The right to Learn : A blueprint for creating schools that work. San Francisco:Jossey-Bass.

5. $\quad$ Frankes, L., Valli, L., \& Cooper, D. H. (1998). Continuous learning for all adults in the professional development school: A review of the research. In D.J. McIntyre \& D. M. Byrd (Eds.) Strategies for careerlong teacher education: Teacher education yearbook VI (pp.69-83). Thousand Oaks, CA: Corwin Press.

6. Freppon, P. A. (2001). What it takes to be a teacher: The role of personal and professional development. Portsmouth, NH:Heinemann.

7. Gioia, D.A. \& Corley, K. G. (2002). Being good versus looking good: Business school rankings and the Circean transformation from substance to image. Academy of Management Learning and Education, 1: 107120.

8. Glennan, T. K. \& Melmed, A. (1996). Fostering the use of educational technology: Elements of a national strategy. Santa Monica, CA: Rand Corporation

9. Long, S. (2004). Separating rhetoric from reality: Supporting teachers in negotiating beyond the status quo. Journal of Teacher Education, 55: 141:153.

10. Pfeffer, J. \& Fong, C.T. (2002). The end of business schools? Less success than meets the eye. Academy of Management Learning and Education, 1: 78-95.

11. Schmotter, J. W. (1984). An interview with Professor James E. Howell. Selections, 16: 9-13.

12. Stake, R. E. (1995). The art of case study research. Thousand Oaks, CA: Sage.

13. Trank, C. Q. \& Rynes, S. L. (2003). Who moved our cheese? Reclaiming professionalism in Business Education. Academy of Management Learning and Education, 2: 189-205.

14. Yin, R. K. (1994). Case study research: Design and methods ( $2^{\text {nd }}$ ed.). Thousand Oaks, CA:Sage.

15. Zimmerman, J. L. (2001). Can American business schools survive? (Working Paper FR 01-16). University of Rochester, Simon School of Business. Available: http://papers.ssrn.com/abstract =283112. 


\section{NOTES}

